\title{
Quality of life in patients after coronary artery bypass grafting with bilateral internal thoracic artery versus single internal thoracic artery
}

\author{
Marcin Zębalski ${ }^{1}$, Jarosław Bis ${ }^{1}$, Michał Krejca², Marek A. Deja ${ }^{1}$ \\ ${ }^{1}$ Department of Cardiac Surgery, Upper-Silesian Heart Center, Katowice, Poland \\ ${ }^{2}$ Department of Cardiac Surgery, Medical University of Lodz, Lodz, Poland
}

Kardiochir Torakochir Pol 2020; 17 (1): 24-28

\begin{abstract}
Introduction: The left internal thoracic artery to the left anterior descending artery graft is recognized as the gold standard for coronary revascularization. We compared quality of life (QoL) in patients who received bilateral internal thoracic arteries (BITA) and those with a single internal thoracic artery (SITA) graft.

Aim: To assess QoL during a 10-year follow-up in patients who underwent coronary artery bypass grafting (CABG) with BITA vs. SITA.

Material and methods: We recruited 300 patients with multivessel coronary artery disease who underwent CABG from January 2005 to October 2010. Mean duration (standard deviation - SD) of follow-up was $3568 \pm 409$ days. QoL was measured subjectively using a Likert scale and objectively by the WHOQOL-BREF questionnaire. Patients were interviewed by telephone.

Results: BITA patients reported marked improvement and improvement more often than SITA patients (58\% vs. $43.3 \%$, $p=0.02)$. Marked deterioration was noted by $2 \%$ of BITA patients and $3.3 \%$ of SITA patients $(p=0.03)$. Summarized results of the WHOQOL-BREF questionnaire showed significantly better QoL in the BITA group (median: 15.0) vs. SITA group (median: 14.75) $(p=0.02)$. There were more angina-free patients in the BITA group (84\%) compared to SITA patients $(72.7 \%)$ ( $p=0.006)$. QoL did not correlate with patients' body mass index $(p=0.10)$ or residence status $(p=0.51)$, but there was a weak negative correlation between QoL and patients' age $(r=-0.14, p=0.01)$.

Conclusions: Surgical coronary revascularization using BITA improves QoL, particularly when measured by a Likert scale.
\end{abstract}

\section{Streszczenie}

Wprowadzenie: Zespolenie pomiędzy lewą tętnicą piersiową wewnętrzną a tętnicą przednią zstępującą lewą stało się złotym standardem w rewaskularyzacji naczyń wieńcowych. Porównaliśmy jakość życia pacjentów (QoL), którzy otrzymali dwie tętnice piersiowe wewnętrzne (BITA), z pacjentami z jedną tętnicą piersiową wewnętrzną (SITA).

Cel: Ocena jakości życia pacjentów z jedną vs dwoma tętnicami piersiowymi wewnętrznymi po 10-letnim okresie od zabiegu pomostowania aortalno-wieńcowego (CABG).

Materiał i metody: Do badania włączono 300 pacjentów, u których przeprowadzono CABG od stycznia 2005 do października 2010 r. Średni czas obserwacji wyniósł $3568 \pm 409$ dni. Pacjentów oceniano subiektywnie przy zastosowaniu skali Likerta i obiektywnie, wykorzystując kwestionariusz WHOQOL-BREF, podczas rozmowy telefonicznej.

Wyniki: Znacznie lepsza QoL wystąpiła stosunkowo częściej u pcjentów z BITA w porównaniu z SITA ( $58 \%$ vs 43,3\%, $p=0,02$ ). Znaczne pogorszenie jakości życia zanotowano u $2 \%$ pacjentów z BITA vs 3,3\% pacjentów z SITA $(p=0,03)$. Sumaryczny wynik kwestionariusza WHOQOL-BREF wskazał znaczną przewagę BITA nad SITA (mediana 15,0 vs 14,75, $p=0,02$ ). W grupie BITA znacznie więcej pacjentów deklarowało brak bóli wieńcowych w porównaniu z grupą SITA ( $84 \%$ vs $72,7 \%, p=0,006)$. QoL nie korelowała ze wskaźnikiem masy ciała $(p=0,10)$ ani ze statusem mieszkaniowym $(p=0,51)$, jednak wiek pacjentów w małym stopniu wpływał na QoL $(r=-0,14, p=0,01)$.

Wnioski: Rewaskularyzacja z użyciem BITA zwiększa QoL, zwłaszcza gdy jest ona mierzona za pomocą skali Likerta.

Słowa kluczowe: tętnica piersiowa wewnętrzna, jakość życia.

Key words: internal mammary artery, quality of life.

Address for correspondence: Marek A. Deja, Department of Cardiac Surgery, Upper-Silesian Heart Center, 47 Ziołowa St, $40-635$ Katowice, Poland, phone: +48 3225260 93, e-mail: mdeja@sum.edu.pl

Received: 15.10 .2019 , accepted: 12.01 .2020$. 


\section{Introduction}

Coronary artery bypass grafting (CABG) is one of the most commonly performed cardiac surgical procedures worldwide and remains a treatment of choice for multivessel coronary artery disease [1]. The standard surgical approach consists in anastomosing the left internal thoracic artery to the left anterior descending coronary artery and using the saphenous vein to bypass the remaining coronary vessels. The internal thoracic artery has superior long-term patency to saphenous vein grafts when used as a conduit in coronary artery bypass surgery [2, 3]. Several reports suggest that using both internal thoracic arteries (bilateral internal thoracic artery - BITA) for grafting is associated with better long-term outcome in comparison to the use of one thoracic artery (single internal thoracic artery - SITA) [4, 5]. Even though the recently published 10-year outcomes of the large, multicenter, randomized Arterial Revascularization Trial (ART) did not show any differences between SITA and BITA approaches with regard to hard endpoints, there might be a benefit in quality of life (QoL) in the BITA population [1].

\section{Aim}

In this study we compared the long-term QoL of SITA and BITA patients. Additionally, we identified pre- and postoperative factors that might determine QoL.

\section{Material and methods \\ Study group}

This study recruited 300 patients with multivessel coronary artery disease who underwent CABG from January 2005 to October 2010 in the Cardiac Surgery Department in Katowice. The first group included 150 (50\%) patients who received BITA. The second group also consisted of 150 patients with SITA. Patients were assigned to groups using a random number generator. Included patients were interviewed by telephone. Those with whom telephone contact could not be established were excluded from the study. They were replaced by new patients using a random number generator until an equal number of patients in both groups was reached.

\section{Evaluation of quality of life}

Subjective QoL was measured using a Likert scale. Patients were asked: "What is your current quality of life compared to the preoperative period?" and subsequently they were prompted to choose one of the following options: marked deterioration, deterioration, no change, improvement or marked improvement.

Objective QoL was assessed using the WHOQOL-BREF questionnaire. WHOQOL-BREF asks how the patient feels about QoL, health and other areas of the patient's life. This questionnaire includes all emotional, social, physical and environmental aspects of the individual's life. It consists of 26 questions from four domains: somatic, psychological, social and environmental. To each question the patient can choose one answer. The answers are ordered from the worst (one point) to the best possible (five points). The points are added up in each domain and converted for transformed scores according to the instructions for the questionnaire. Our project obtained permission of the World Health Organization to use the questionnaire for this purpose.

Perioperative data were collected from hospital records. On interview patients were asked additionally about any cardiac events, repeat revascularization, severity of angina symptoms, and others.

\section{Statistical analysis}

Obtained results were analyzed using the IBM SPSS Statistics Version 22 software. Follow-up data obtained from patients were compared between patients with BITA vs. SITA. Descriptive analyses were performed as estimation of frequencies, mean values and standard deviations (quantitative variables) and as percentages (qualitative variables). The $t$-test and Mann-Whitney test depending on normal distribution were used to compare quantitative variables. To compare qualitative variables, we used the $\chi^{2}$ test or Fisher's test. Statistical significance $(p<0.05)$ was verified by means of appropriate tests. For demonstrating the correlation between QoL and variables Spearman correlations were used.

\section{Results}

Perioperative data of patients are shown in Table I and results obtained from telephone interview in Table II. Tele-

Table I. Baseline characteristic in the time of operation

\begin{tabular}{|c|c|c|c|}
\hline Variable & BITA & SITA & $P$-value \\
\hline Number of patients & 150 & 150 & \\
\hline Age [years] & $57.5 \pm 8.7$ & $59.4 \pm 8.7$ & 0.05 \\
\hline Male gender & $128(85.3 \%)$ & $117(78 \%)$ & 0.14 \\
\hline $\mathrm{BMI}\left[\mathrm{kg} / \mathrm{m}^{2}\right]$ & $27.7 \pm 3.3$ & $27.9 \pm 4.1$ & 0.74 \\
\hline Obesity & $31(20.7 \%)$ & $43(28.7 \%)$ & 0.11 \\
\hline Diabetes & $27(18 \%)$ & $35(23.3 \%)$ & 0.32 \\
\hline Hypertension & $136(90.7 \%)$ & 142 (95\%) & 0.39 \\
\hline LVEF (\%) & $51.5 \pm 8.7$ & $52.2 \pm 9.3$ & 0.45 \\
\hline Nicotine dependency & 24 (16.1\%) & $30(20 \%)$ & 0.27 \\
\hline \multicolumn{4}{|l|}{ NYHA: } \\
\hline 1 & 87 (58\%) & $93(62 \%)$ & \multirow[t]{4}{*}{0.24} \\
\hline 2 & $58(38.7 \%)$ & $46(30.7 \%)$ & \\
\hline 3 & $5(3.3 \%)$ & $10(6.7 \%)$ & \\
\hline 4 & 0 & $1(0.7 \%)$ & \\
\hline \multicolumn{4}{|l|}{ CCS: } \\
\hline 0 & 0 & $2(1.3 \%)$ & \multirow[t]{5}{*}{$<0.001$} \\
\hline 1 & $38(25.3 \%)$ & $23(15.3 \%)$ & \\
\hline 2 & 78 (52\%) & $62(41.3 \%)$ & \\
\hline 3 & $33(22 \%)$ & 47 (31.3\%) & \\
\hline 4 & $1(0.7 \%)$ & $16(10.7 \%)$ & \\
\hline
\end{tabular}

Data are presented as mean with standard deviation or $n$ with percent. BITA - bilateral internal thoracic artery, SITA - single internal thoracic artery, $\mathrm{BMI}$ - body mass index, LVEF - left ventricular ejection fraction, NYHA New York Heart Association, CCS - Canadian Cardiovascular Society. 
Table II. Data of patients obtained during telephone interview

\begin{tabular}{|c|c|c|c|}
\hline Variable & BITA $(n=150)$ & SITA $(n=150)$ & $P$-value \\
\hline Age [years] & $67.5 \pm 9$ & $69 \pm 8.7$ & 0.14 \\
\hline BMI $\left[\mathrm{kg} / \mathrm{m}^{2}\right]$ & $26.8 \pm 4.1$ & $27.8 \pm 3.7$ & 0.02 \\
\hline Observation [days] & $3643.4 \pm 420.1$ & $3492.1 \pm 384.2$ & $<0.001$ \\
\hline \multicolumn{4}{|c|}{ Repeat revascularization: } \\
\hline $\mathrm{PCl}$ & $31(20.7 \%)$ & 39 (26\%) & 0.34 \\
\hline CABG & $2(1.3 \%)$ & $1(0.7 \%)$ & $>0.99$ \\
\hline Myocardial infarction & $3(2 \%)$ & $9(6 \%)$ & 0.14 \\
\hline Diabetes & $55(36.7 \%)$ & $55(36.7 \%)$ & $>0.99$ \\
\hline Hypertension & $115(76.5 \%)$ & $140(93.3 \%)$ & $<0.001$ \\
\hline Nicotine dependency & $24(16.1 \%)$ & $30(20 \%)$ & 0.45 \\
\hline Living alone & $32(21.3 \%)$ & $24(16 \%)$ & 0.30 \\
\hline Working patient & $31(20.7 \%)$ & $18(12 \%)$ & 0.06 \\
\hline \multicolumn{4}{|l|}{ NYHA: } \\
\hline 1 & $105(70 \%)$ & $87(58 \%)$ & 0.14 \\
\hline 2 & $37(24.7 \%)$ & $49(32.7 \%)$ & \\
\hline 3 & $8(5.3 \%)$ & $13(8.7 \%)$ & \\
\hline 4 & 0 & $1(0.7 \%)$ & \\
\hline \multicolumn{4}{|l|}{ CCS: } \\
\hline 0 & 126 (84\%) & 109 (72.7\%) & 0.006 \\
\hline 1 & $11(7.3 \%)$ & $5(3.3 \%)$ & \\
\hline 2 & $8(5.3 \%)$ & 23 (15.3\%) & \\
\hline 3 & $5(3.3 \%)$ & $12(8 \%)$ & \\
\hline 4 & 0 & $1(0.7 \%)$ & \\
\hline
\end{tabular}

Data are presented as mean with standard deviation or $n$ with percent. BITA - bilateral internal thoracic artery, SITA - single internal thoracic artery, $\mathrm{BMI}$ - body mass index, $\mathrm{PCl}$ - percutaneous coronary intervention,

CABG - coronary artery bypass grafting, NYHA - New York Heart Association, CCS - Canadian Cardiovascular Society.

Table III. Quality of life by Likert scale

\begin{tabular}{|c|c|c|c|}
\hline Quality of life & BITA $(n=150)$ & SITA $(n=150)$ & $P$-value \\
\hline Marked deterioration & $3(2 \%)$ & $5(3.3 \%)$ & 0.03 \\
\hline Deterioration & $16(10.7 \%)$ & 27 (18\%) & \\
\hline No change & $44(29.3 \%)$ & $53(35.3 \%)$ & \\
\hline Improvement & $61(40.7 \%)$ & $54(36 \%)$ & \\
\hline Marked improvement & $26(17.3 \%)$ & $11(7.3 \%)$ & \\
\hline
\end{tabular}

Data are presented as $n$ with percent. BITA - bilateral internal thoracic artery, SITA - single internal thoracic artery.

Table IV. Quality of life by WHOQOL-BREF Questionnaire

\begin{tabular}{lccc} 
Domain & BITA $(n=150)$ & SITA $(n=150)$ & $P$-value \\
Somatic & $14.4 \pm 2.1$ & $13.9 \pm 2.5$ & 0.101 \\
\hline Psychological & $15.5 \pm 2$ & $15 \pm 2.1$ & 0.068 \\
\hline Social & $15.3 \pm 2.2$ & $14.6 \pm 2.3$ & 0.026 \\
\hline Environmental & $15.6 \pm 1.8$ & $14.8 \pm 2.1$ & 0.002 \\
\hline
\end{tabular}

Data are presented as mean with standard deviation. BITA - bilateral internal thoracic artery, SITA - single internal thoracic artery.

phone interviews were held approximately 10 years after CABG but this time was shorter in the SITA group (3492.1 vs. 3643.4 days, $p<0.001$ ). Mean duration of observation in both groups was $3568 \pm 409$ days.

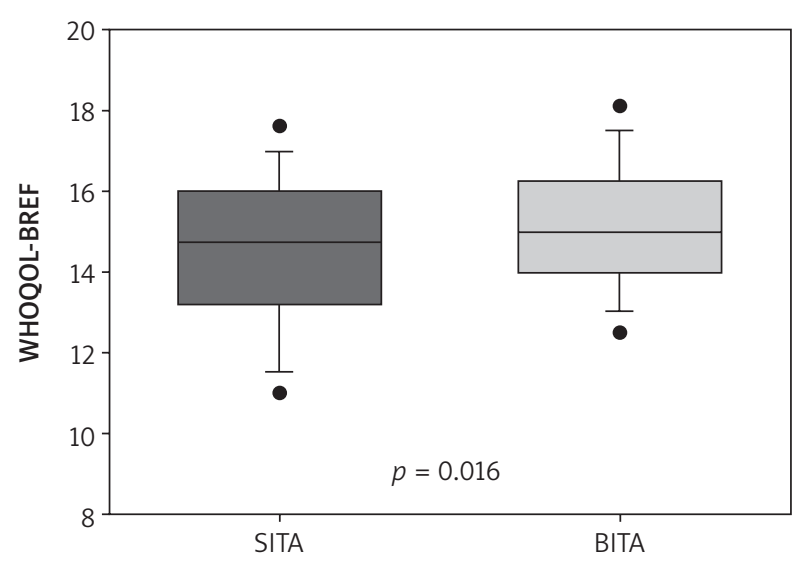

Figure 1. Summary result of WHOQOL-BREF questionnaire in the group with single internal thoracic artery vs. bilateral internal thoracic artery group

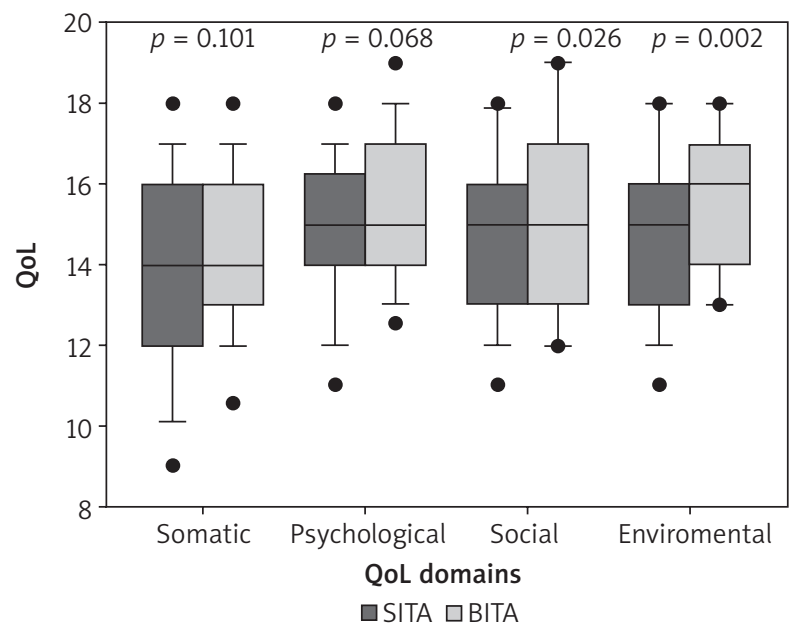

Figure 2. Quality of life (QoL) in four domains of WHOQOL-BREF questionnaire

Our study showed significant difference in angina symptoms measured by the Canadian Cardiovascular Society (CCS) scale in patients before and after CABG. In the BITA group $84 \%$ of patients did not complain of angina after surgery in comparison to $72.7 \%$ in the SITA group ( $p=0.006)$.

QoL compared with the preoperative period based on the Likert scale revealed superiority of BITA compared with SITA - Table III. BITA patients reported marked improvement and improvement more often than SITA patients ( $58 \%$ vs. $43.3 \%, p=0.02$ ). Marked deterioration was noted by $2 \%$ of BITA patients and $3.3 \%$ of SITA patients $(p=0.03)$. Summarized results of the WHOQOL-BREF Questionnaire also show significantly better QoL in the BITA group (median: 15.0) vs. the SITA group (median: 14.75) ( $p=0.02)$ - Figure 1. Among four domains of the WHOQOL-BREF Questionnaire BITA patients had significantly better QoL in two domains: environmental $(p=0.002)$ and social $(p=0.03)$. In psychological and somatic domains the differences between the groups were not significant ( $p=0.07$ and $p=0.10$ respectively). All four domains are presented in Table IV and in Figure 2. 
In both groups more than $20 \%$ of patients required percutaneous coronary intervention ( $\mathrm{PCl}$ ) in the postoperative period $(20.7 \%$ vs. $26 \%, p=0.34)$ - Table II. Two percent of patients with bilateral thoracic grafts suffered from myocardial infarction during 10-year observation compared with $6 \%$ of SITA patients $(p=0.14)$. Redo CABG was performed in $2(1.3 \%)$ BITA patients and $1(0.7 \%)$ SITA patient $(p=0.56)$.

QoL did not correlate with patients' BMI $(p=0.10)$ or residence status $(p=0.51)$. However, there was a weak negative correlation $(r=-0.14, p=0.01)$ between $\mathrm{QoL}$ and the patients' age (Figure 3). Social and environmental domains correlated with patients' age (somatic: $r=-0.137, p=0.02$, environmental: $r=-0.17, p=0.003$ ). Along with increasing symptoms of heart failure measured by New York Heart Association class (NYHA) there was a correlation with QoL $(r=-0.27, p<0.001)$. NYHA class mostly affected somatic and psychological domains $(r=-0.291, p<0.001$ and $r=-0.217$, $p<0.001)$. We found that the severity of angina assessed with the CCS scale had the most important impact on QoL $(r=-0.344, p<0.001$, Figure 4$)$ especially in the somatic domain $(r=-0.36, p<0.001)$. Our study shows that working patients have better QoL than retired patients $(p=0.005)$. The most important difference was found in the somatic domain (median: 15.0 vs. 14.0, $p<0.001$ ).

\section{Discussion}

The aim of our study was to define the QoL of patients with BITA grafts compared with SITA. Previous studies showed that the internal thoracic artery has better longterm patency than the saphenous vein used as a graft in CABG [2, 3, 6, 7]. Internal thoracic artery (ITA) graft has a 10 -year rate of angiographic patency exceeding $90 \%$, as compared with $50 \%$ for vein grafts [7]. Therefore, one can expect better long-term outcomes when both ITA are used for CABG. BITA grafting is technically more challenging and time consuming because both mammary arteries must be harvested sequentially [8]. We have evaluated the QoL of patients as an indirect determinant of graft performance. Other determinants include frequency of repeat revascularization, incidents of myocardial infarction and severity of angina measured by CCS classification. Based on this reliable assessment tool, in this study we established that QoL can be a marker of therapeutic effectiveness.

In this study BITA patients were a little younger than SITA patients but the follow-up period is longer in the BITA group. In the BITA group patients reported better QoL compared to SITA. Apart from better QoL in BITA patients we observed better postoperative outcomes in this group, as more BITA patients were angina free compared to SITA patients. However, the frequency of myocardial infarction incidents and the need for $\mathrm{PCl}$ were similar in both groups. It is important that ultimately there were more angina-free patients in the BITA group, as it was demonstrated in previous research that frequency of angina attacks is a major factor influencing QoL $[9,10]$. Comparison of both groups at long-term follow-up led us to the conclusion that BITA has an advantage over SITA.

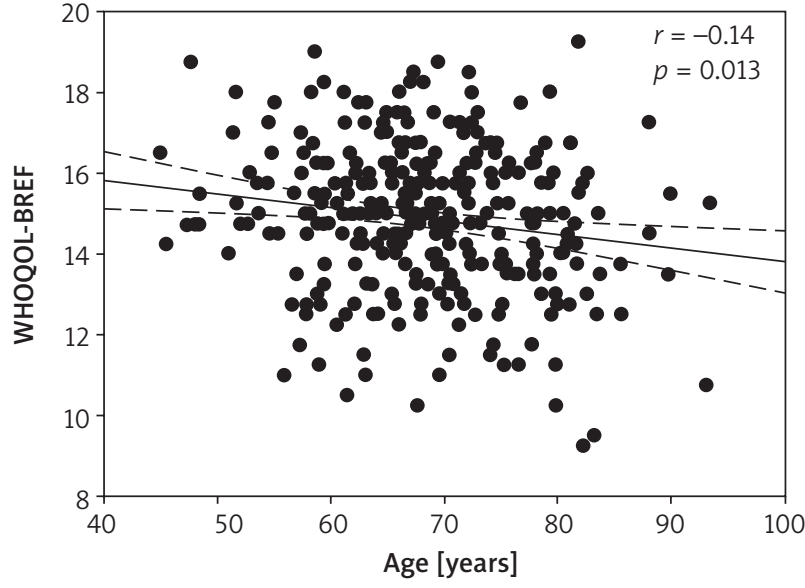

Figure 3. Impact of patients' age on quality of life

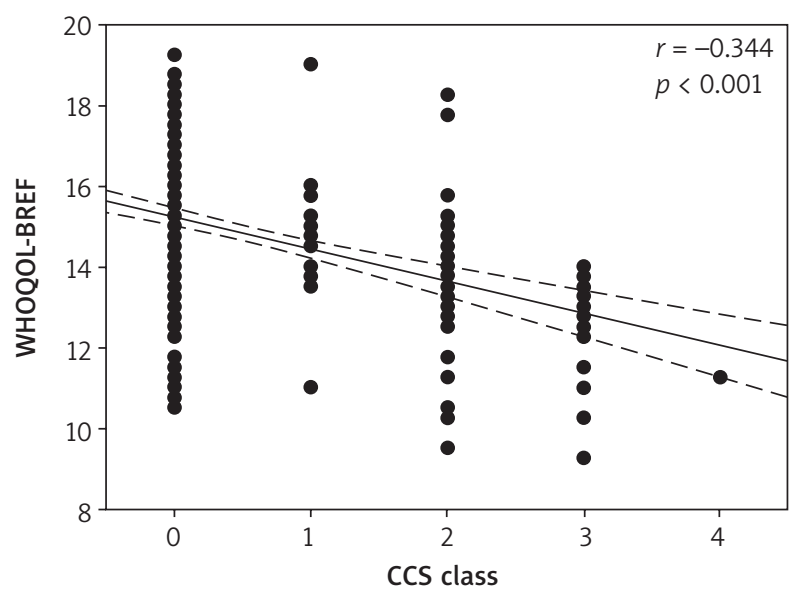

Figure 4. Impact of severity of angina measured by Canadian Cardiovascular Society on quality of life

Many studies have shown a positive impact of CABG on QoL in short-, mid- or long-term follow-up [10-15]. Our results strengthen this notion by demonstrating that the use of both ITA adds to the improvement of QoL. Hokkanen et al. [14] observed improved QoL 12 years after CABG compared with preoperative values despite progressing deterioration. In their study improvement of QoL measured by the RAND-36 questionnaire was seen in all dimensions but at 12-year follow-up was smaller than one year after surgery [14]. Rumsfeld et al. [15] confirmed improvement of QoL after revascularization by $\mathrm{CABG}$ and $\mathrm{PCI}$. They compared 6-month health-related QoL after CABG vs. PCI but did not find any differences [15]. We believe that at long-term follow-up using both ITA has an advantage over the CABG using one ITA and particularly over $\mathrm{PCl}$. In a Polish study published by Krzych et al. better QoL after minimally invasive totally endoscopic atraumatic coronary artery bypass grafting (EACAB) was proven [10]. The authors noted that patient's age has no impact on QoL. In our study we observed deterioration in QoL in elderly patients similarly to other investigations [14].

In the ART study there were no significant differences between BITA and SITA groups with regard to the rate of death from any cause, myocardial infarction or repeat revascularizations [1]. This could be caused by the short fol- 
low-up period. Similar early outcomes after BITA and SITA grafting were also reported by Walkes et al. [16]. Benefit of using arterial grafts is usually revealed at long-term followup. For that reason QoL can be one of the first determinants of conduit patency.

There is a scarcity of studies comparing QoL after CABG in patients who received BITA vs. SITA. Kurlansky et al. [17] analyzed QoL of patients who received BITA. They compared the outcome of men and women and found no differences in relation to gender [17]. Similarly, we did not find any correlation between QoL and gender $(p=0.35)$.

Our study shows that retired patients have worse QoL compared to working patients. On one hand better conduit patency can influence their health and improve the ability to work but on the other hand working patients were significantly younger than retired ones (60 vs. 69.8 years, $p<0.001$ ).

Apart from better QoL in BITA patients we showed better postoperative outcomes in this group. More BITA patients were angina free compared to SITA patients. Necessity of repeat revascularization was similar in both groups. We recorded a relatively high rate of repeat revascularizations in both study groups $-20.7 \%$ and $26 \%$ within 10 years in BITA and SITA groups respectively. These values are relatively high in comparison to the results of the ART study where the repeat revascularization rate of $10 \%$ at 10 -year follow-up was noted. However, there are studies reporting significantly higher repeat revascularization rates. In the study by Marui et al. within 5 years after CABG $14 \%$ of patients had repeat revascularizations [18]. In another study there were $14.3 \%$ repeat revascularizations during 5 -year follow-up after previous CABG [19].

We find our results somewhat disappointing. We expected a clearer difference in favor of the BITA group. We thought that the difference would be more expressed in somatic and psychological domains, which should better reflect cardiac patients' outcomes.

There were some limitations of this study. Firstly, most of the data were collected retrospectively from patients. We did our best to collect data as diligently as possible. Each patient was precisely informed about the study. Nevertheless, data collected from hospital records could have been more reliable than those obtained from patients. Secondly, for the full rating of QoL it seems justified to check the patient's QoL status prior to CABG. Our patients were not randomized. Although both groups were comparable in terms of clinical characteristics there is one more factor that could have had an impact on our results. Patients who are in better general condition, aware of their illness, are more likely to be assigned by the operating surgeon to CABG with BITA.

\section{Conclusions}

This study showed better QoL in the BITA group, especially when measured by the Likert scale. To obtain more conclusive results, a randomized study should be performed.

\section{Disclosure}

The authors report no conflict of interest.

\section{References}

1. Taggart DP, Benedetto U, Gerry S, Altman DG, Gray AM, Lees B, Gaudino M, Zamvar V, Bochenek A, Buxton B, Choong C, Clark S, Deja M, Desai J, Hasan R, Jasinski M, O'Keefe P, Moraes F, Pepper J, Seevanayagam S, Sudarshan C, Trivedi U, Wos S, Puskas J, Flatcher M. Bilateral versus single internal thoracic artery grafts at 10 years. N Engl J Med 2019; 380: 437-446.

2. Hlatky MA, Shilane D, Boothroyd DB, Boersma E, Brooks MM, Carrie D, Clayton TC, Danchin N, Flatcher M, Hamm CW, Hueb WA, Kahler J, Lopes N, Pocock SJ, Rodriguez A, Serruys P, Sigwart U, Stables RH. The effect of internal thoracic artery grafts on long-term clinical outcomes after coronary bypass surgery. J Thorac Cardiovasc Surg 2011; 142: 829-835.

3. Loop FD, Lytle BW, Cosgrove DM, Stewart RW, Goormastic M, Williams GW, Golding LA, Gill CC, Taylor PC, Sheldon WC, Proudfit WL. Influence of the internal-mammary-artery graft on 10-year survival and other cardiac events. N Engl J Med 1986; 314: 1-6.

4. Yi G, Shine B, Rehman SM, Altman DG, Taggart DP. Effect of bilateral internal mammary artery grafts on long-term survival: a meta-analysis approach. Circulation 2014; 130: 539-545.

5. Buttar SN, Yan TD, Taggart DP, Tian DH. Long-term and short-term outcomes of using bilateral internal mammary artery grafting versus left internal mammary artery grafting: a meta-analysis. Heart 2017; 103: 1419-1426.

6. Sabik JF, Lytle BW, Blackstone EH, Houghtaling PL, Cosgrove DM. Comparison of saphenous vein and internal thoracic artery graft patency by coronary system. Ann Thorac Surg 2005; 79: 544-551.

7. Taggart DP, Altman DG, Gray AM, Lees B, Gerry S, Benedetto U, Flatcher M. Randomized trial of bilateral versus single internal-thoracic-artery grafts. N Engl J Med 2016; 375: 2540-2549.

8. Ejiofor Jl, Kaneko T, Aranki SF. Current readings: single vs bilateral internal mammary artery in coronary artery bypass grafting. Semin Thorac Cardiovasc Surg 2018; 30: 398-405.

9. Cohen DJ, Hout B V, Serruys PW, Mohr FW, Macaya C, Heijer P, Vrakking MM, Wang K, Mahoney EM, Audi S, Leadley K, Dawkins KD, Kappetein AP. Quality of life after $\mathrm{PCl}$ with drug-eluting stents or coronary-artery bypass surgery. N Engl J Med 2011; 364: 1016-1026.

10. Krzych LJ, Lach M, Mustafa S, Joniec M, Niemiec M, Abu Samra R, Bochenek A, Cisowski M. Quality of life in patients after minimally invasive endoscopic atraumatic coronary artery bypass grafting: a long-term follow-up. Kardiol Pol 2012; 70: 890-896.

11. Jarvinen O, Saarinen T, Julkunen J, Huhtala H, Tarkka MR. Changes in healthrelated quality of life and functional capacity following coronary artery bypass graft surgery. Eur J Cardiothorac Surg 2003; 24: 750-756.

12. Rumsfeld JS, Magid DJ, O'Brien M, McCarthy M, MaWhinney S, Shroyer AL, Moritz TE, Henderson WG, Sethi GK, Grover FL, Hammermeister KE. Changes in health-related quality of life following coronary artery bypass graft surgery. Ann Thorac Surg 2001; 72: 2026-2032.

13. Favarato ME, Hueb W, Boden WE, Lopes N, Nogueira CR, Takiuti M, Gois AF, Borges JC, Favarato D, Aldrighi JM, Oliveira SA, Ramires JA. Quality of life in patients with symptomatic multivessel coronary artery disease: a comparative post hoc analyses of medical, angioplasty or surgical strategies-MASS II trial. Int J Cardiol 2007; 116: 364-370.

14. Hokkanen M, Jarvinen O, Huhtala H, Tarkka MR. A 12-year follow-up on the changes in health-related quality of life after coronary artery bypass graft surgery. Eur J Cardiothorac Surg 2014; 45: 329-334.

15. Rumsfeld JS, Magid DJ, Plomondon ME, Sacks J, Henderson W, Hlatky M, Sethi G, Morrison DA. Health-related quality of life after percutaneous coronary intervention versus coronary bypass surgery in high-risk patients with medically refractory ischemia. J Am Coll Cardiol 2003; 41: 1732-1738.

16. Walkes JCM, Earle N, Reardon MJ, Glaeser DH, Wall MJ, Huh J, Jones JW, Soltero ER. Outcomes in single versus bilateral internal thoracic artery grafting in coronary artery bypass surgery. Curr Opin Cardiol 2002; 17: 598-601.

17. Kurlansky PA, Traad EA, Galbut DL, Singer S, Zucker M, Ebra G. Coronary bypass surgery in women: a long-term comparative study of quality of life after bilateral internal mammary artery grafting in men and women. Ann Thorac Surg 2002; 74: 1517-1525.

18. Marui A, Nishiwaki N, Komiya T, Hanyu M, Tanaka S, Kimura T, Sakata R. Comparison of 5-year outcomes after coronary artery bypass grafting in heart failure patients with versus without preserved left ventricular ejection fraction (from the CREDO-Kyoto CABG registry cohort-2). Am J Cardiol 2015; 116: 580-586.

19. Shiomi H, Morimoto T, Furukawa Y, Nakagawa Y, Tazaki J, Sakata R, Okabayashi H, Hanyu M, Shimamoto M, Nishiwaki N, Komiya T, Kimura T. Comparison of five-year outcome of percutaneous coronary intervention with coronary artery bypass grafting in triple-vessel coronary artery disease (from the coronary revascularization demonstrating outcome study in Kyoto $\mathrm{PCl} /$ CABG registry cohort-2). Am J Cardiol 2015; 116: 59-65. 